\title{
Strategy for Return to General Surgical Elective Surgeries in Controlled COVID-19 Pandemic
}

\section{Kontrollü COVID-19 Pandemisinde Genel Cerrahi Elektif Ameliyatlarına Geri Dönüş Stratejisi}

\author{
(1) Erdinc Kamer ${ }^{1}$, ๑ Tahsin Çolak ${ }^{2}$ \\ ${ }^{1}$ Katip Çelebi University Atatürk Training and Research Hospital, Department of Surgery, İzmir, Turkey \\ 2Mersin University Faculty of Medicine, Department of General Surgery, Mersin, Turkey
}

\begin{abstract}
HIIIIIII ABSTRACT
In these days when the COVID-19 pandemic was under control, a strategy was intended to be developed in the light of international literature to safely return to routine surgical activities and elective surgical operations. For related research articles, a literature review was conducted in all of PubMed, Wos, Google Scholar, Elsevier, Scopus, EBSCO indexes. In addition, the World Health Organization, Ministry of Health, COVID-19 declaration of the scientific board, Turkish Surgical Association, Turkish Society of Colon and Rectal Surgery, Turkish Medical Association, the U.S. Centers for Disease Control, the American Association of Surgeons, the European Union and other relevant information on the websites of the state health agency was searched. The focus was mainly on high-quality studies and on patient flow and safety of health workers during outpatient and elective surgery practices. The scattered information and limited number of literature in the above-mentioned sites, the information and personal experiences obtained from the studies were presented as a strategic algorithm. In the covid-19 crisis, there is a serious elective surgery burden, as elective surgery operations in both the outpatient clinic and the operating room have abruptly ceased. Since it is not possible to remove this load at once, a phased start scenario needs to be planned. The exact timing depends largely on factors beyond our control. Once the restrictions are terminated, clinical and surgical volume will gradually increase. Therefore, it will be necessary to prioritize cases by categorizing them.
\end{abstract}

Keywords: Surgical, Covid-19, elective, pandemic

\section{|||||||||| ÖZ}

COVID-19 pandemisinin kontrol altına alındığı bu günlerde rutin cerrahi aktivitelere ve elektif cerrahi operasyonlara güvenli bir şekilde geri dönmek için uluslararası literatür ışı̆̆ında bir strateji geliştirilmesi amaçlandı. İlgili araştırma makaleleri için PubMed, WoS, Google Scholar, Elsevier, Scopus, EBSCO indekslerinin tümünde literatür taraması yapılmıştır. Ayrıca, Dünya Sağlık Örgütü, Sağlık Bakanlığı, COVID-19 Bilimsel Kurulu beyanları, Türk Cerrahi Derneği, Türk Kolon ve Rektum Hastalıkları Derneği, Türk Tabipleri Birliği, ABD Hastalık Kontrol Merkezleri, Amerikan Cerrahlar Birliği, Avrupa Birliği ve diğer devlet sağlığı ajansı web siteleri ilgili bilgiler tarandı. Özellikle, yüksek kaliteli çalışmalar, poliklinikler ve elektif cerrahi uygulamaları sırasında hasta akışını ve sağlık çalışanlarının güvenliğini konu alan çalışmalara odaklanıldı.

Yukarıda adı geçen sitelerde dağınık şekildeki bilgiler ve kısıtlı sayıda literatür çalışmalardan elde edilen bilgiler ve kişisel deneyimler stratejik bir algoritma haline getirilerek sunuldu. Covid-19 krizi hem poliklinik hem de ameliyathanedeki elektif cerrahi operasyonlar aniden durdurduğundan, ciddi bir elektif cerrahi yükü mevcuttur. Bu yükün birden kaldırılması mümkün olmadığından aşamalı bir başlangıç senaryosunun planlanması gerekmektedir. Tam zamanlama büyük ölçüde kontrolümüz dışındaki faktörlere bağlıdır. Kısıtlamalar kaldırıldıktan sonra, klinik ve cerrahi hacim giderek artacaktır. Bu nedenle olguları kategorize ederek öncelendirmek gerekecektir.

Anahtar Kelimeler: Cerrahi, Covid-19, elektif, pandemi

Address for Correspondence/Yazışma Adresi: Erdinç Kamer MD,

Katip Çelebi University Atatürk Training and Research Hospital, Department of Surgery, İzmir, Turkey

E-mail: erdinc.kamer@gmail.com ORCID ID: orcid.org/0000-0002-5084-5867

国- Received/Geliş Tarihi: 25.05.2020 Accepted/Kabul Tarihi: 27.05.2020

${ }^{\circ}$ Copyright 2020 by Turkish Society of Colon and Rectal Surgery

Turkish Journal of Colorectal Disease published by Galenos Publishing House. 


\section{Introduction}

A new corona virus, named Severe Acute Respiratory Syndrome-Coronavirus-2 (SARS-CoV-2) by World Health Organization (WHO) and causing Coronavirus Disease 2019 (COVID-19) disease, caused a pneumonia outbreak in Wuhan, Hubei, China in December 2019, and this outbreak was soon spread to other states of China and then to the whole world, primarily the European continent. ${ }^{1,2}$ Following the introduction of COVID-19 into the pandemic disease group by WHO in January/2020, measures such as maintaining a widespread social distance, closing of workplaces, implementing curfew and using health resources more effectively have been taken in many countries. ${ }^{3}$ Due to the lack of sufficient knowledge in managing the COVID-19 pandemic and the lack of experience in how to operate the infected or suspected cases and how to prepare the health teams for these operations and the inability to foresee the number of patients who will apply to health organizations, elective and postponable operations were halted during the pandemic process, emergency surgery or surgical procedures requiring the detection of some cancer cases continued to work. In our country, after the first COVID-19 patient was seen on 11/03/2020, according to the recommendations of the COVID-19 Scientific Board formed by the Ministry of Health, taking into consideration the recommendations of the WHO, many arrangements had to be made in the health services. In particular, these measures to minimize the density in health care facilities, health care providers and reducing the burden on health care resources and the energy to be used in the most healthy way of [personal protective equipment (PPE), inpatient services, intensive care beds etc.] to be used in the most accurate way has been taken. One of these measures was to take the necessary measures to plan non-urgent elective surgery procedures as far as possible to a more appropriate date in the article sent to health institutions by the General Directorate of Health Services of the Ministry of Health on 17/03/2020. ${ }^{4}$ It was preferred by most health care providers and surgeons not to perform elective surgeries as of $17 / 03 / 2020$, only to perform urgent and some cancer surgeries. ${ }^{5}$ However, due to this situation, especially postponing of procedures such as endoscopy and colonoscopy, using imaging methods such as computed tomography in the diagnosis and followup of COVID-19, due to the patients' complaints about not being hospitalized due to illness or late admission, it was observed that some cancer diseases such as skin, breast, cervix and colorectal cancers began to diagnosed late. ${ }^{6,7}$ As a result of these delays, there may be progress in the stage of the disease and changes in the treatment protocols to be applied.
The postponement or cancellation of elective operations and diagnostic procedures such as endoscopy/colonoscopy is a huge problem that will be very difficult for the health system to handle in the future. ${ }^{8}$ The postponement of timedependent elective operations such as Transplant surgery has the potential to lead to worsening health of people with such diseases, lower quality of life and unexpected deaths. ${ }^{8,9}$ On the other hand, when suspended elective operations are resumed, it is possible to expect that the time of hospitalization will be longer and complications will increase to some extent, depending on the type of operation that is held and the deterioration in the general condition of the patient. However, some basic factors that may prevent the resumption of elective surgery, for example, lack of doctors, nurses and auxiliary health personnel because of the disease and quarantine; as a result of the inability to process to the supply chain of a suture, surgical staples, such as deficiencies in the material; the appropriate operating room, anesthesiologists and anesthesia, the presence of the appropriate equipment for the intensive care unit (ICU) beds, such as ensuring the adequacy of conditions should be taken into consideration.

In a study showing how many cases were delayed during the 12 -week period when the corona virus peaked ${ }^{10}$, it was determined that approximately 28.5 million cases were delayed or cancelled around the world, and the majority of these cases were benign. In addition, the average postponement was found to be over $70 \%$, with $80 \%$ of benign cases and $37 \%$ of cancer cases being delayed. In the same study, it was suggested that it would take about 45 weeks to clear these delayed cases. This study is important for revealing the extent of the problem. ${ }^{10}$

On the other hand, following the control of the COVID-19 pandemic in our country and the determination of the slowdown in the cases, a normalization plan was presented by Turkish Republic Presidency and declerated to the public on 04/05/2020. In this plan, it is declared that the normalization process will be carried out in a "dynamic" manner depending on the course of the outbreak at domestic and abroad and a manual containing the measures to be implemented during the normalization period in May/2020 and training of professional groups to be determined by the Ministry of Health is planned. On the other hand, it is planned that hospitals will begin normal outpatient and elective surgery procedures and pandemic hospitals will be reduced in the period of June/ 2020. ${ }^{11}$

In this process we are preparing to normalize, this includes potential benefits such as having a normalization strategy for general surgeons, protecting the surgical teams against the risk of infection, as well as solving the huge workload ahead of general surgeons without problems under a 
specific plan and minimizing the risk of a second wave in the COVID-19 pandemic. The aim of this paper is to propose a return strategy considering the current strategies in the international literature to return efficiently and safely to normal outpatient activities and delayed elective surgery operations after the COVID-19 pandemic we are undergoing.

\section{Materials and Methods}

The medical literature on how to perform elective operations under the conditions of the COVID-19 pandemic was extensively reviewed. Search engines and indexes such as "PubMed", "Web of Science" "EBSCO", "Google Scholar" "Elsevier" and "Scopus" were used for this review. The words "COVID-19, corona virus, normalization, elective operations and surgery" were used as key words. The collected articles on this subject were examined in terms of the normalization plan and proposals. In addition, the web sites of WHO, the American Association of Surgeons, Ministry of Health, COVID-19 Scientific Committee, the Turkish Surgical Society (TSS), Turkish Society of Colon and Rectal Surgeons (TSCRS), Turkish Medical Association (TTB) Turkish Anesthesiology and Reanimation Society, and other non-governmental organizations (NGOs) related to COVID-19, the European Union and other states were searched, and relevant information were evaluated. The personal opinions and written statements of experienced authorities regarding the COVID-19 pandemic were also considered. Studies and articles containing safety measures for patients and health teams during outpatient and routine medical interventions, proposing the patient flow and elective operations' management strategy were considered. Articles and studies on COVID-19 were found to generate a high rate of heterogeneity. Due to the very limited number of articles proposing a return strategy to outpatient clinic and elective surgery operations, this information was combined with personal experience and management plans of the authorities to create a return strategy proposal.

\section{Results and Conclusion}

A road map has been set out in preparation of the turnaround plan, taking into account some of the compelling or restrictive factors. It was proposed that this roadmap/strategy should be grouped under two main headings: general principles and principles of return to elective surgery:

\section{General Principles}

1. First, a planning of the return to elective cases is necessary. This planning should be in a dynamic process. In this process, the involved institutions, Ministry of Health, universities, COVID-19 Science Board, local representatives of $\mathrm{WHO}$, professional associations such as
TSS, TSCRS and TTB and other public health-related NGOs should be managed in a multidisciplinary manner and the process should be directed by assessing the course of the pandemic in society and the effects of elective operations on the pandemic. Especially, Ministry of Health is a direct determinant on the State and City Hospitals, since it is an indirect but strong determinant on university hospitals and private/foundation hospitals, it can be a facilitator and guide for preparing a guide on when and how to start elective operations. In the "Presidential Normalization Plan" presented on 04/05/2020, the Ministry of Health has declared that it will prepare a guide in May. ${ }^{11}$

2. There is still an abstention in our country and in the world regarding the transition to elective surgery. As is known, a potential increase in post-operative morbidity and mortality was noted in patients undergoing major surgery during incubation of COVID-19 infection in China. ${ }^{12}$ It is reported that the incubation period of COVID-19 infection varies between 0-14 days and the average incubation period is 5 days. In this case, the fact that our patients who are going to perform elective surgery are not known during the incubation period will bring important problems. During perioperative period, caution will be required when starting elective surgeries in order to avoid increased mortality and morbidities in patients developing COVID-19, to reduce viral spread within the hospital, to prevent health workers from becoming infected and to reduce the spread of the virus outside the hospital. ${ }^{13,14}$ According to WHO data between 31/12/2019-05/05/2020 due to New Coronavirus disease (COVID-19) in the world 3.517.345 number of cases, 243.401 number of deaths were seen; in our country, Ministry of Health announced as of $10 / 05 / 2020$ total 129,491 number of cases, 3,520 number of deaths. ${ }^{15}$ In the WHO status report dated 05/05/2020, there were 1832 new cases, 59 new deaths in Turkey and the virus was widely circulated in society. ${ }^{16}$ Since the number of cases and deaths reported by the Ministry of Health are limited to "Reverse Transcription Polymerase Reaction (PCR)" and cases, and individuals who can be identified as COVID-19 carriers in the community are not yet known, extra tests may be needed to identify these individuals before elective surgery. In Turkey, the possibility of transmission of the infection is "high" and its effect/severity in the community is "moderate", assessed as a "high risk as a result. Overall risk is defined as a combination of the probability and impact of a health threat $($ Risk $=$ probability X effect $) .{ }^{16}$ At present, caution is needed in switching to elective surgeries in an environment where the possibility of infection is "high risk". In light of all these, COVID-19 testing is required for the patients with whom we plan the 
operation and, if it has not been performed, all medical personnel before elective surgery planning. COVID-19 antigen and antibody test, SARS-CoV real-time reverse transcription polymerase chain reaction (rrt-PCR) test may be performed to assess active transmission or exposure to the virus. ${ }^{17}$ It is not recommended to be used in surgical patients due to the variable results of rapid kit tests to control antibodies. ${ }^{18}$

3. When returning to elective operations, COVID-19 should be diverted from widespread pandemic hospitals to centers where COVID-19 suspected/positive patients are collected and no longer cared for as the outbreak subsides. If this is not possible it may be necessary to create isolated COVID-19 services and use the rest of the hospital. It is very important that training for the new status of staff is carried out under the control of infection committees and discipline should not be abandoned in this regard. To prevent the recurrence of this viral infection, health workers will need to be trained to accept and abide by changes, and their behavior will need to be changed, with the implementation of the standard working protocol to manage post-COVID-19 situations.

4. In large cities and relatively peripheral areas outside these cities, there are many factors that can force recovery after COVID-19. Unemployment and economic stagnation caused by the pandemic will have a negative impact on patients requiring surgery. In addition, the availability of implants and various operating materials may be hampered by international and national travel restrictions. On the other hand, the increase in demand for supply firms and the decrease in supply offered, the increase in production and costs will be reflected as the inevitable result of the surgical services offered, increasing costs to both the state and the people receiving services and/or insurance companies. Access to COVID-19 Tests should also be facilitated before starting elective operations in deprived areas and/or in extreme towns and settlements of our country. Surgery-related morbidity is still based on very little evidence; therefore, prioritizing conservative treatments if possible will help balance the morbidity and mortality of patients until experience is gained.

5. National TV channels and social media are widely needed to keep COVID-19 sensitivity alive and in order to reach patients and the community with the updated information. All healthcare professional and patients should be checked against COVID-19 symptoms before entering the hospitals. In addition, online registration and use of technology by patients are encouraged. Isolation should be managed by infection control guidelines and committee prior to surgery.
6. Measures against the possibility of a second wave - It is important not to ignore the possibility of a second wave, following the participation of workplaces and tourism areas in social life and relaxation of stay-athome policies and occasional curfews as parts of the normalization. It may be necessary to be on constant alert to detect new COVID-19 cases between the weeks and months following the slowdown in new cases. Therefore, COVID-19 protection measures and social distance should not be waived.

\section{Principles of Return to Elective Surgery}

1. Timing of the Return to Surgery initiation - Based on the scientific literature, since incubation time of COVID-19 is reported to be 5-14 days in order to be normalized and to initiate elective operations, it can be said that there should be a continuous decrease in COVID-19 cases nationally and regionally before starting elective or partially elective operations. ${ }^{19}$ Besides, to determine the time to start elective operations, it should be ensured that there are sufficient ventilators, PPE and ICU beds for post-operative care and that there are sufficient (at least 30 days) equipment and logistics material in the operating room. Continuing elective surgeries or reopening the hospital should be presented to the Government Health officials who are concerned with the National COVID management action plan by a commission of surgery unit representative, anesthesia and reanimation unit representative, infectious diseases unit representative, public health unit representative, and administrative unit representative in that healthcare organization and it must also be approved by the Ministry of Health.

2. As it is known, during the COVID-19 pandemic, quite experience was gained in the surgery of infected patients and many scientific papers have been presented on this subject. $^{2,20,21}$ These procedures may need to be revised for patients, healthcare professionals (such as anesthesia, surgical team, staff) and other patients within elective surgery, taking into account the procedures applied to infected patients before surgery, during the surgery and after surgery. Patients on elective surgery waiting lists and their consent forms should be re-evaluated. In addition, informed consent forms including surgical pathologies, suitability for surgery, and complications may arise due to COVID-19 pandemic, are required to be reorganized and also reviewed. Patients' desire to have surgery under these new conditions should be determined. Since it is not yet known what complications and physiological responses will be faced in a scenario of a controlled COVID-19 pandemic and after, it may be appropriate to adopt an approach which is supported with limited current literature but also 
experience based. Today, the following are known as the risk factors for a patient that is worsen the COVID-19 table;

- Old age $>65$

- Cardiovascular disease (Hypertension, coronary artery disease, congestive heart failure)

- ASA: 3 and higher

- BMI >35

- Diabetes Mellitus

- Autoimmune diseases

- Blood transfusion history

- Hypercoagulant cases

- Immunosuppressive drugs (steroid use/rheumatology drugs/organ transplantation drugs)

- Renal Disease (Glomerulonephritis/renal failure, etc.)

- Lung Diseases (COPD, asthma, interstitial lung disease, pulmonary fibrosis, pulmonary hypertension)

- Obstructive sleep apnea

- Cigarettes and electronic cigarettes

It is important to evaluate these risk factors when selecting patients. ${ }^{22}$ Serious preoperative evaluation will be required to reduce the postoperative complication risks with the medical evaluation supported by preoperative evaluation, to detect the asymptomatic transport of COVID-19, and to evaluate the surgical suitability to reduce the demand for postoperative ICU. ${ }^{23}$ According to the suggestions of The International Society of Aesthetic Plastic Surgery, for the elective surgery at the first stage; they suggest selecting patients with $<65$ years of age, ASA 1-2, estimated operating time $<3$ hours, with no a coexistent disease. ${ }^{22}$ Epidemiological evaluation of patients should be made before the elective surgery. Patients should be asked if they have had a close contact with a possible or confirmed case in the last 14 days, a history of coming from abroad and contact with a person from abroad. Clinical evaluation such as cough, fever, sore throat, headache, asthenia, muscle pain, dyspnea or arthralgia, diarrhea, tremor, nausea or vomiting, recent onset hyposmia or anosmia should be performed. It is recommended to include certain tests such as C-reactive protein, $\mathrm{r}(\mathrm{PCR})$ for SARS-CoV-2, specific immunoglobulin (Ig) $\mathrm{M}$ and IgG in routine blood tests performed before the surgery. ${ }^{13}$ In other words, we believe that it will be useful to include in the above-mentioned tests as well as the hepatitis panel and human immunodeficiency virus panel tests which are in our routine practice when preparing the patient in the preoperative period. In their study, Luo and Zhoung ${ }^{14}$ reported that it would be beneficial to look for influenza, serum respiratory virus, Conjoint test, M. pneumonia antibodies, liver function tests, creatine kinase, troponin, CRP, ESR, procalcitonin, D-Dimer/Fibrinogen degradation products as blood tests. ${ }^{14}$ Thoracic CT imaging is not recommended as a screening test in asymptomatic cases by the Turkish Anaesthesiology and Reanimation Society. In suspicious cases, thoracic CT imaging is recommended before the operation for further evaluation in the presence of symptoms such as fever, cough and respiratory distress, and PCR testing is recommended in all non-emergency patients. According to the institution's test capacity and rapid conclusion, two negative PCR results in the last 72 hours or one in the last 24 hours should be seen in each patient. ${ }^{24}$ Pulmonary X-ray imaging is routinely recommended. However, in one study, many surgeons expressed the opinion that low-dose pulmonary CT should be taken before the surgery. Considering the false negativity rate of the PCR test, all elective surgical patients should be evaluated as COVID-19 suspected patients and wear a surgical mask, and the approach in the operating room should be built on the same result. ${ }^{24}$ Of course, evaluating the patients only will not be enough. Health status of surgeons, anesthesiologists, nurses (operating room, post-operative care, intensive care and service staff), technicians and all other auxiliary medical personnel will also need to be evaluated. The aim should be to provide diagnosis and treatment to COVID-19negative patients by COVID-19-negative health personnel. Every healthcare professional should either be negative or recovered from symptomatic COVID-19 with negative reverse transcriptase-PCR tests (two negative results separated by 48 hours may be ideal) or should have specific immune test results for SARS-CoV-2 such as IgM-negative and IgG-positive. Considering the incubation period, we would like to draw a little more attention to the feasibility of the things described above. Despite taking all these precautions, the patient should be told about these situations in detail and should be told -without worrying- that there is a risk of getting COVID-19 infection, and clarified consent must be obtained. Any patient (elective or emergency) who has not developed an antibody for at least a six-month period should be treated as COVID suspect, a single room should be arranged for these patients, and patient care should be done with the PPE specified in the protocols. ${ }^{24}$ It is important to apply respiratory physiotherapy in preoperative period to the patients scheduled for elective surgery and to start low molecular weight heparin treatment for patients at risk group, and to wash the oral and nasal cavity with povidone iodine.

3. The classification of General Surgery diseases is recommended as follows:

I. Category (A): Diseases requiring "Emergency" surgery, including diseases that may result in life/organ/limb loss if not identified and intervened within 24 hours at the latest. For example; trauma injuries, sharp object injuries, acute abdominal cases (such as perforation, mechanical intestinal obstruction, peritonitis-causing diseases) 
II. Category (B): Diseases that require "Semi-Emergency" surgery, which includes diseases that are expected to progress if it is not treated within a few weeks. For example: Some colorectal diseases (semi-occlusive colon or rectal cancer, asymptomatic colon cancers, rectal cancers unresponsive to neoadjuvant therapy, early stage rectal cancers where adjuvant therapy is not appropriate), bariatric surgery (revisions for dysphagia, severe reflux, pain, dehydration/ malnutrition, slipped band, anastomosis strictures with aspiration risk), some breast diseases (patients who have completed neoadjuvant therapy, Stage T2 or N1, ER positive/PR positive/HER2 negative tumors, triple negative or HER2 positive patients, incompatible biopsies that may be malignant, malignant recurrence excisions). ${ }^{25,26,27}$

III. Category (C): Diseases requiring "Semi-Elective" surgery, which involves organ loss or organ dysfunction in the near future, or diseases that may make future surgery dangerous if surgery is not performed. For example; symptomatic cholelithiasis, some colorectal diseases (pre-endoscopic resection or non-resection malignant polyps, large, benign asymptomatic polyps, small, asymptomatic colon or rectal carcinoid tumors), some breast diseases (fibroadenoma, such as excision of benign lesions, incompatible biopsies that may be benign, high-risk atypical lesions, prophylactic surgery in cases with or without cancer, delayed sentinel lymph node biopsy detected by excisional biopsy, cTisNOER positive and negative lesions, re-excision surgeries, tumors that respond to neoadjuvant hormonal therapy, clinical stage T1N0 estrogen receptor positive/progesterone receptor positive/HER2 negative tumors, inflammatory and locally advanced breast cancers. ${ }^{25,27}$

IV. Category (D): Diseases which are non progressive and requiring "elective" surgery that can be operated within 1 year. For example; hernia surgery, benign tumors diagnosed with biopsy, benign thyroid diseases, symptomatic cholelithiasis, bariatric surgery, benign anorectal diseases. ${ }^{26}$ Surgeries aimed on improving the patient's quality of life, if the patient's quality of life has been stable for the past year, may be delayed or shifted until the intensity of operations started after COVID-19 has passed. On the other hand, a different approach should be taken in patients with diabetes mellitus, chronic organ dysfunction, or chemo/radiotherapy with associated immunosuppression. If these patients need to undergo major surgery, isolation must be mandatory at least two weeks before surgery to ensure that these patients do not carry coronavirus. First of all, we think that it is important to start elective surgeries by selecting cases who have been postponed, patients without concomitant disease, short-term cases, outpatient procedures that do not require hospitalization, under 65, ASA 1-2 patient group, and uncomplicated surgeries that do not require blood transfusion.

4. Operating room and personnel planning - Operating room staff training and PPE training should be provided. The use of PPE and isolation measures should be given great importance, especially in procedures requiring anesthesia induction and especially in procedures requiring the use of aerosol-producing surgical instruments, and in procedures where contact with the patient's body fluids is highly likely. A separate operating room complex should be allocated for emergency surgery involving patients with suspected or infected COVID-19. These complexes should have separate access, different infrastructure and a separate exit. If suspicious cases are to be operated, it is recommended to have HEPA (High-Efficiency Particulate Air) Filter/Laminar flow to provide high-frequency and rapid air exchange in the operating room to reduce viral contamination. The number of personnel and doctors required during the surgical procedure in the operating room should be kept minimum. Care should be taken to ensure that the surgical seniority and isolation training of this team is reasonable. Instruments producing aerosols such as electro-cautery, insufflator, sealing devices should be used to a minimum or should not be used in surgical procedures. After the procedure, the operating room should undergo an extensive cleaning and disinfection before it can be used for new patients. It should be ensured that equipment, such as anesthesia devices, is completely decontaminated according to the disinfection guidelines. The number of patients in the operating room list should be fewer than normal and some operating rooms should be kept as backup. The virus can remain on surfaces that have not been cleaned for up to 9 days. The virus can be eliminated with $70 \%$ ethanol, $0.1 \%$ sodium hypochlorite or $0.5 \%$ hydrogen peroxide. Nobody should enter the room for at least 15 minutes after the patient leaves the room, then cleaning should be done afterwards. The inter-operative time (at least 60 minutes) reserved for cleaning should be followed, and the number of operations performed during the day should be reduced. Disposable materials should be used as much as possible in the operating room, and instruments to be reused should be sent from the operating room to sterilization in two red bags. There should not be extra consumables in the operating room, they should be asked one by one whenever necessary. If possible, it should be ensured that there is an infection control responsible in the operating room; and under their supervision, monitoring the use of the PPE by the operating room staff is ensured.

5. Postoperative care - The length of hospital stay after surgery should be kept to a minimum and if patient needs such as postoperative dressing and venous antibiotics are 
not vital, these applications should be encouraged to be done at home. It may be possible to avoid or reduce face-toface interviews by following most of these operated patients via telephone or video calls. ${ }^{28}$ However, separate follow-up areas can be created to assess venous thromboembolism, and vital complications such as deep surgical infections.

6. Regular and continuous control of the operated patients through telemedicine or video media is important to minimize re-hospitalization or recalls by reducing the likelihood of developing complications. Therefore, it is necessary to make more intensive use of this new formation (computer-assisted communication) that the COVID pandemic has added to our lives.

As a result, we are of the opinion that; initially, surgery for every patient as if they are COVID-19 suspect will be a precaution for the protection of both the patient and other healthcare professionals. In addition, this article presented above has been prepared under the light of the up-to-date medical literature until its publication. New publications are presented to the literature every day. After a while, the information mentioned above may need to be revised. We believe that it will be beneficial for every Healthcare Institution and doctor to follow up-to-date information provided by the Republic of Turkey Ministry of Health along with the current medical literature.

Peer-review: Internally peer-reviewed.

\section{Authorship Contributions}

Concept: E.K., T.Ç., Design: E.K., T.Ç., Data Collection or Processing: E.K., T.Ç., Analysis or Interpretation: E.K., T.Ç., Literature Search: E.K., T.Ç., Writing: E.K., T.Ç.

Conflict of Interest: No conflict of interest was declared by the authors.

Financial Disclosure: The authors declared that this study received no financial support.

\section{References}

1. He F, Deng Y, Li W. Corona virus Disease 2019 (COVID-19): What we know? J Med Virol 2020. https://doi.org/10.1002/jmv.25766574.

2. Kamer E, Colak T. What to Do When A Patient Infected With COVID-19 Needs An Operation: A Pre-surgery, Peri-surgery and Post-surgery Guide. Turk J Colorectal Dis 2020;30:1-8.

3. Zeegen EN, Yates AJ, Jevsevar DS. After the COVID-19 Pandemic: Returning to Normalcy or Returning to a New Normal? J Arthroplasty 2020;508835403:30427.

4. T.C. Sağllk Bakanlığı Sağllk Hizmetleri Genel Müdürlüğünün 17.03.2020 tarih ve 14500235-403.99-E.546 sayll, "Elektif İșlemlerin Ertelenmesi ve Diğer Alınacak Tedbirler" konulu yazısı. https://dosyamerkez.saglik. gov.tr/Eklenti/36865, elektif-islemlerin-ertelenmesi-ve-diger-tedbirlerpdf. pdf?0

5. COVID Surg Collaborative. Global guidance for surgical care during the COVID-19 pandemic. Br J Surg 2020. doi:10.1002/bjs.11646.
6. Three Months of COVID-19 May Mean 80,000 Missed Cancer, Diagnoses https://www.medscape.com/viewarticle/929986

7. Fewer Cancer Diagnoses During COVID-19 in the Netherlands. https:// www.medscape.com/viewarticle/930179

8. Soreide K, Hallet J, Matthews JB, Schnitzbauer AA, Line PD, Lai PBS, Otero J, Callegaro D, Warner SG, Baxter NN, Teh CSC, Kamstra JN, Meara JG, Hagander L, Lorenzon L. Immediate and long-term impact of the COVID-19 pandemic on delivery of surgical services. Br J Surg 2020. doi: 10.1002/bjs.11670.

9. Grass F, Behm KT, Duchalais E, Crippa J, Spears GM, Harmsen WS Hübner M, Mathis KL, Kelley SR, Pemberton JH, Dozois EJ, Larson DW. Impact of delay to surgery on survival in stage I-III colon cancer. Eur J Surg Oncol 2020;46:455-461

10. COVIDSurg Collaborative, Nepogodiev D, Bhangu A. Elective surgery cancellations due to the COVID-19 pandemic: global predictive modelling to inform surgical recovery plans. BJS 2020. https://doi.org/10.1002/ bjs.11746.

11. Cumhurbaşkanlı̆̆ Normalleşme Planı, 04.05.2020 https://www.tccb gov.tr/haberler/410/119206/-normal-hayata-donusu-kademe-kademebaslatacagiz-

12. Lei S, Jiang F, Su W, Chen C, Chen J, Mei W, Zhan LY, Zhang L, Liu D, Xia ZY, Xia Z. Clinical charesteristics and outcomes of patients undergoing surgeries during the incubation period of COVID-19 infection. E Clinical Medicine 2020, https://doi.org/10.1016/j.eclinm.2020.100331

13. J Mayol J, Fernández Pérez C. Elective surgery after the pandemic: waves beyond the horizon. Br J Surg 2020. https://doi.org/10.1002/bjs.11688

14. Luo Y, Zhong M. [Standardized diagnosis and treatment of colorectal cancer during the outbreak of novel coronavirus pneumonia in Renji hospital]. Zhonghua Wei Chang Wai Ke Za Zhi 2020;23:E003.

15. Türkiye'deki Güncel Durum, Sağlık Bakanlığı, https://covid19.saglik.gov. tr/

16. HASUDER: Halk Sağlı̆̆ı Uzmanlanı Derneği. Yeni Koronavirüs Hastalığı (COVID-19) Pandemisine Türkiye'de Hazırllık ve Yanit: 56. Gün Değerlendirmesi, 10.05.2020. https://korona.hasuder.org.tr/turkiyedehazirliklilik-ve-yanit-56-gun-degerlendirmesi/

17. Centers for disease control and prevention.2019 Novel Coronavirus (2019$\mathrm{nCoV}$ ) Situation summary. https://www.cdc.gov/coronavirus/2019-ncov/ casesupdates / summary

18. Mallapaty S. Will antibody tests for the coronavirus really change everything? Nature 2020;580:571-572.

19. Gottleib S, McClellan M, Silvis L, Rivers C, Watson C. National coronavirus response: A road map to reopening. American Enterprise Institute website. https://www.aei.org/research products/report/nationalcoronavirusresponse-a-road-map-to reopening/. March 29, 2020. (Accessed April 17 , 2020).

20. Karaca AS, M. Ozmen M, Ucar D, Yastı C, Demirer S. General Surgery Operating Room Practice in Patients with COVID-19. Turk J Surg 2020;36:1-5

21. Lacy AM, Lacy FBD, Balibrea JM. Considerations for transanal total mesorectal excision (TaTME) use during the COVID-19 pandemic. Br J Surg 2020;107:e203

22. Plastik Rekonstrüktif ve Estetik Cerrahi Uzmanları için Covid-19 Pandemi Rehberi,15/05/2020.http://dernek.plastikcerrahi.org.tr/tprecdDATA/ Uploads/files/covidv3pages-1.pdf

23. Stahel PF. How to risk-stratify elective surgery during the COVID-19 pandemic? Patient Saf Surg. 2020;14:8.

24. Türk Anesteziyoloi ve Reanimasyon Derneği, Anesteziyoloji ve Reanimasyon Uzmanları İçin, COVID-19 Pandemisi Normalleşme Döneminde Elektif Cerrahilere Başlama Önerileri, 21/05/2020, file:///C:/ Users/pc/Downloads/COVID-Elektif-Cerrahilere-Basslama-Kilavuzu2.1.pdf 
25. ACS, COVID-19 and Surgery. COVID-19 Guidelines for Triage of Colorectal Cancer Patients 24/03/2020. https://www.facs.org/covid-19/ clinical-guidance/elective-case/colorectal-cancer

26. ACS, COVID-19 and Surgery . COVID-19 Guidelines for Triage of Metabolic and Bariatric Surgery Patients 24/03/2020. https://www.facs. org/covid-19/clinical-guidance/elective-case/metabolic-bariatric
27. ACS, COVID-19 and Surgery. COVID-19 Guidelines for Triage of Breast Cancer Patients 24/03/2020, https://www.facs.org/covid-19/clinicalguidance/elective-case/breast-cancer

28. Iyengar K, El-Nahas W. A brief guide to telephone medical consultation. Br J Healthc Manag 2020. https://doi.org/10.12968/bjhc.2020.0032 